\title{
Estimation of forest litter fractions by regression analysis in different aged stands of Pinus nigra
}

\author{
Estimación de los patrones del mantillo por análisis de regresión \\ en rodales de Pinus nigra de diferentes edades
}

\author{
Hüseyin Barış Tecimen a,b,*, Orhan Sevgi a , Osman Yalçın Yılmaz c, \\ Serdar Carus d, Ali Kavgacı ${ }^{\text {e, }}$, Serdar Akburak ${ }^{\text {a }}$ \\ *Corresponding author: ${ }^{a}$ Istanbul University-Cerrahpaşa, Faculty of Forestry, Soil Science and Ecology Department, \\ 34473 İstanbul, Turkey, hbarist@gmail.com \\ ${ }^{\mathrm{b}}$ University of Florida, Indian River Research and Education Center, Institute of Food and Agricultural Sciences, \\ 34945, Fort Pierce, FL, USA. \\ c Istanbul University- Cerrahpaşa, Faculty of Forestry, Department of Measurement and Cadastre, 34473 İstanbul, Turkey. \\ d Suleyman Demirel University, Faculty of Forestry, Biometry and Yield Department, Isparta, Turkey. \\ ${ }^{\mathrm{e}}$ West Mediterranean Forest Research Institute, Antalya, Turkey.
}

\section{SUMMARY}

Forest litter (FL) carbon accumulation patterns can be predicted by certain tree and stand parameters to assess how variably managed forests may accumulate carbon. The aim of our study was to use tree stand data to refine methods to predict the composition of FL fragments in temperate, semi-humid black pine forests (Pinus nigra) in western Anatolia, Turkey. Predictive models were established between FL fractions (fine fragments of $<2,2-4$, and $>4 \mathrm{~mm}$ and coarse woody debris of branches $<5 \mathrm{~cm},>5 \mathrm{~cm}$, cones and bark) and tree parameters (stand age, tree height, diameter at breast height, tree basal area, tree density, lowest tree crown height and tree crown thickness). We sampled 105 stands of ages $<50,50-100$, and $>100$ years, that were distributed at 5 altitudinal steps (500 to $1,750 \mathrm{~m})$. A multi-regression analysis was used to estimate FL fraction for different-age stands. Total FL dry biomass varied from 18 to $213 \mathrm{Mg} / \mathrm{ha}$ (average: $94 \mathrm{Mg} / \mathrm{ha}$ ). The fine fragment fraction ( $>4 \mathrm{~mm}$ ) represented the largest proportion of FL (36\%). Coarse woody debris amounted for 6.6-7.8 \% of the FL and branches $<5 \mathrm{~cm}$ accounted for the highest proportion (12.4-26.4 \%) of coarse woody debris. The most influential parameters predicting FL fragment proportions included dry branch thickness, thinning rate, height and age $\left(\mathrm{R}^{2}: 0.11\right.$ to 0.67$)$. The combination of long-term observation and fine and coarse litter trapping methods should improve the estimation rates of sequestered carbon in forest ecosystems.

Key words: black pine, dry branch thickness, forest litter, stand age.

\section{RESUMEN}

Los patrones de acumulación del mantillo posiblemente se pueden predecir por ciertos parámetros del árbol y rodal para evaluar cómo los bosques manejados por diferentes métodos acumulan carbono. El objetivo de este estudio fue usar datos de parcelas de árboles para refinar métodos que predicen la composición de los tamaños de fragmentos del mantillo en bosques templados semi-húmedos de pino negro (Pinus nigra) en el occidente de Anatolia, Turquía. Se establecieron modelos predictivos entre los componentes del mantillo (fragmentos finos de $<2,2-4$ y $>4 \mathrm{~mm}$ y detrito leñoso grueso de ramas de $<5 \mathrm{~cm},>5 \mathrm{~cm}$, piña y corteza) y parámetros de los árboles (edad, altura, dap, área basal, densidad, altura del comienzo de copa y su diámetro). Se muestrearon 105 parcelas (edades $<50$, 50$100,>100$ años) distribuidas en cinco altitudes (500-1.750 m). Mediante análisis de multiregresión se estimaron las cantidades de los componentes del mantillo. El mantillo varió de 18 a $213 \mathrm{Mg} / \mathrm{ha}$ (promedio: $94 \mathrm{Mg} / \mathrm{ha}$ ). Los fragmentos finos (>4 mm) representaron la mayor proporción (36\%). El detrito leñoso grueso representó 6,6-7,8\%; las ramas $<5$ cm fueron la mayor proporción de este componente (12,4-26,4 \%). Las variables más influyentes para predecir las proporciones de los componentes del mantillo incluyeron el grosor de las ramas secas, tasa de raleo, altura y edad. La combinación de las observaciones de largo plazo y los métodos de captura del detrito fino y grueso deben mejorar las tasas de estimación del carbono secuestrado en los ecosistemas forestales.

Palabras clave: pino negro, grosor las ramas secas, mantillo, edad. 


\section{INTRODUCTION}

Researches have attempted to estimate the carbon amount sequestered in forests either as live biomass or dead litter (Fahey et al. 2010). The high cost of data collection for models prompted scientists and policy makers to seek effortless methods such as less parameter requiring models. The variety of the ecosystem types and dynamics in carbon pools of diverse forests present a complex challenge.

Changes occur in sequestered carbon of terrestrial ecosystems by forests, related to different management regimes. The forest litter is composed of fine forest litter and coarse woody debris which account for $0.28 \mathrm{Pg} /$ year $\left(\mathrm{Pg}=10^{15} \mathrm{~g}\right)$ of the terrestrial carbon sink in the northern hemisphere (Goodale et al. 2002). The carbon stored in forest litter has a key importance for global carbon cycling, hydrological processes, nutrient cycling (Carnol and Bazgir 2013) and greenhouse gas emissions. Based on the importance of forest litter to the global carbon cycle, accurate estimation and monitoring the status of annual carbon sequestration by forest litter is critical (Woodall et al. 2012).

The relationships between forest litter carbon distribution and tree stand properties should be investigated to improve our understanding of the elemental and decomposition cycles within forest litter layers (Oe-Oi) that are dependent on tree and stand structure. Ranius et al. (2003) modeled forest litter amount and distribution among size fractions, although estimation models mainly focused on decay processes and nutrients released from decomposed organic matter (Olajuyigbe et al. 2011). Efforts to quantify leaf and coarse woody debris input to the forest litter focuses on nutrient cycling in forest ecosystems (Saarsalmi et al. 2007). Since the forests are major sinks for terrestrial carbon, the lag times of carbon release as a result of decomposition are often related to site and environmental conditions. As the forest litter carbon amount is a function of litter input (accumulation) and litter decomposition (subtraction), data on stand properties are needed to make predictions about forest litter quantities. Stand properties such as canopy structure (Penne et al. 2010), branch mortality (Maguire 1994) and stand density (Hennessey et al. 1992) are shown to be major factors regulating forest litter carbon distribution and accumulation models. According to a study by Hale et al. (1999), coarse woody debris accumulation and distribution patterns vary according to stand age, species diversity and live tree characteristics. Maguire (1994) hypothesizes that differential crown recession and crown development among stands of variable density may provide an opportunity to control the input of fine woody litter into the forest ecosystem by manipulating stand density.

Black pine (Pinus nigra Arnold.) is a southern European species that extends from Spain into the west to central Turkey in the east (Lučić et al. 2000) and covers an area of 4.2 million hectares in Turkey (Anonymous 2006). It is most intensively distributed in the Alaçam Mountains in Kütahya - Balıkesir provinces. These forests have been managed since the 1950's by the Turkish General Directorate of Forestry following forest management plans. During management activities, the stand structure is controlled by cuttings and thinning operations. The post-harvest residuals of trees comprise the main source of forest litter. Ground skidding of logs causes removal and random accumulation and distribution of forest litter in stands. Thus, forest harvesting operations have impacts on the distribution of litter on forest litter by sweeping, piling and turning down while logging.

Some research on ecological and yield properties at Alaçam mountains have been done (Sevim 1954), but there is still a lack of knowledge on the relationship between forest litter distribution and stand properties. Within the current study, models have been calculated by incorporating selected tree and stand property parameters that were measured in the field and the relations between those parameters and dry litter biomass have been estimated. In this context, the objectives were to (i) determine the differentiation of forest litter fractions through stand age classes, (ii) identify relationships between stands properties and forest litter patterns, and (iii) specify the most efficient parameters to predict forest litter carbon accumulation.

\section{METHODS}

Study site. The study area is located in northwestern Turkey between $39^{\circ} 38^{\prime} 00^{\prime \prime}$ - 39 $07^{\circ} 30^{\prime \prime}$ northern latitudes and $29^{\circ} 15^{\prime} 30^{\prime \prime}-28^{\circ} 15^{\prime} 00^{\prime \prime}$ eastern longitudes. Sampling points were determined by using parent rock maps, stand maps and Shuttle Radar Topography Mission data layers in geographical information systems. Sampling points were distributed to five altitudinal grades from 500 to $1,750 \mathrm{~m}$ with $250 \mathrm{~m}$ steps concluding the sampling altitude intervals: $500-750 \mathrm{~m}, 751-1,000 \mathrm{~m}, 1,001-1,250 \mathrm{~m}$, $1,251-1,500 \mathrm{~m}, 1,501-1,750 \mathrm{~m}$. The sampling plots were selected from five parent rock formations including tuff-agglomerate, granite, melange, dacite and Paleozoic metamorphic rock. Meteorological data was obtained by interpolating the data of the closest meteorological station. According to re-calculated climatic data, the annual mean precipitation is 548 and $927 \mathrm{~mm}$ and the annual mean temperature is 12.1 and $6.7^{\circ} \mathrm{C}$ for the elevations $500 \mathrm{~m}$ and $1,750 \mathrm{~m}$, respectively.

Sampling and measuring stand parameters. The ages of sampled stands ranged between 24 and 212 years of which the highest frequency between ages was 50-100. We compared the stands according to ages $<50$ (young stands), 50-100 (mature stands) to $>100$ (old stands) years which correspond to 20,63 and 22 stands respectively. The samples were collected from 1,279 sampling points with 95 young, 808 mature and 376 old stands. The age classification has been made to collect results per stand growth stage that are consistent with the forest management stand 
classifications. The ages of trees were determined by counting the year rings on the pencils cored from 5 to 15 trees per stand. Canopy closures were visually predicted between the values 0.1 and 1.0. The sizes of the sampling plots were $100,400,900$ and $2,500 \mathrm{~m}^{2}$ to provide a minimum of 50 trees per plot. Height, lowest height of dry branch and crown thickness were measured by Vertex III Laser instruments for each tree in the sampled stand (figure 1). Each tree diameter was measured by caliper from two dimensions. The basal area for each tree was calculated as circle area, summed for each plot and multiplied with conversion factors $100,25,11.11$ and 4 to convert 1 hectare to the sampling plot sizes of 100, 400, 900 and $2,500 \mathrm{~m}^{2}$, respectively. Stand densities were calculated according to Clutter (1983). Dominant tree height was assessed by determining the height value of the median tree among the tallest 100 trees in a stand from the standheight graph (Kalıpsız 1982). The productivity index or the productivity class was obtained from the black pine productivity index table (Kalıpsiz 1982), and the volume of each tree was calculated and converted to value per ha. Mean values for each sampling plot and general properties of parameters assumed to be relevant variants on stand dynamics are listed in table 1. Variables used in the models for single trees are illustrated in figure 1.

Forest litter sampling. Within the current study, we defined the forest litter as the total detritus material laying above the mineral soil composed by leaves (L) (very recently shed light brown leaves which have length or width $>4 \mathrm{~mm}$ ), decomposing layer (F) (brown or dark brown, keeps the morphological traces of the original substance
2-4 $\mathrm{mm}$ ), humus $(\mathrm{H})$ (humified and in a fine grainy form organic layer which lays between mineral soil and decomposing layer $<2 \mathrm{~mm}$ ) classified herein as fine forest litter and coarse woody debris as bark pieces, branches $(>5 \mathrm{~cm}$ and $<5 \mathrm{~cm}$ ) and cones. The additional branch, cone and bark parts found in fine forest litter samples were added back to coarse woody debris fractions. All samples were weighed after drying in oven at $65{ }^{\circ} \mathrm{C}$ for 24 hours. The thickness of this layer changed from 0 to $20 \mathrm{~cm}$ depending on the stand structure and forest litter micro-physiography. The sampling plot selection criterion include altitude, parent rock, exposure, stand age and productivity index. In total 105 plots were sampled. Sub-sampling of forest litter samples were made systematically to avoid subjectivity (figure 2). Sub-sampling was made from 3, 5, 10 and 36 replications of $1 \mathrm{~m}^{2}$ quadrates at 100,400, 900 and $2,500 \mathrm{~m}^{2}$ size sampling plots, respectively. Initially the coarse woody debris were collected in plastic bags from a $1 \mathrm{~m}^{2}$ quadrate to be classified into sub-fractions such as branches ( $>5 \mathrm{~cm}$ and $<5 \mathrm{~cm}$ ), bark and cones. Fine forest litter samples were collected using a ring $(\mathrm{r}=11.25 \mathrm{~cm})$ with three replicates from the same $1 \mathrm{~m}^{2}$ quadrates.

Data analyses. The weight of forest litter fractions obtained from fine forest litter and coarse woody debris were converted into 1 ha area values. A multi-regression analysis was applied for estimation of forest litter fraction patterns in SPSS 17v using the "step by step" method. The parameters with less than 0.05 significance were used for the model equations. The equations with the highest significance and containing the fewest variables were chosen and evaluated for the model.

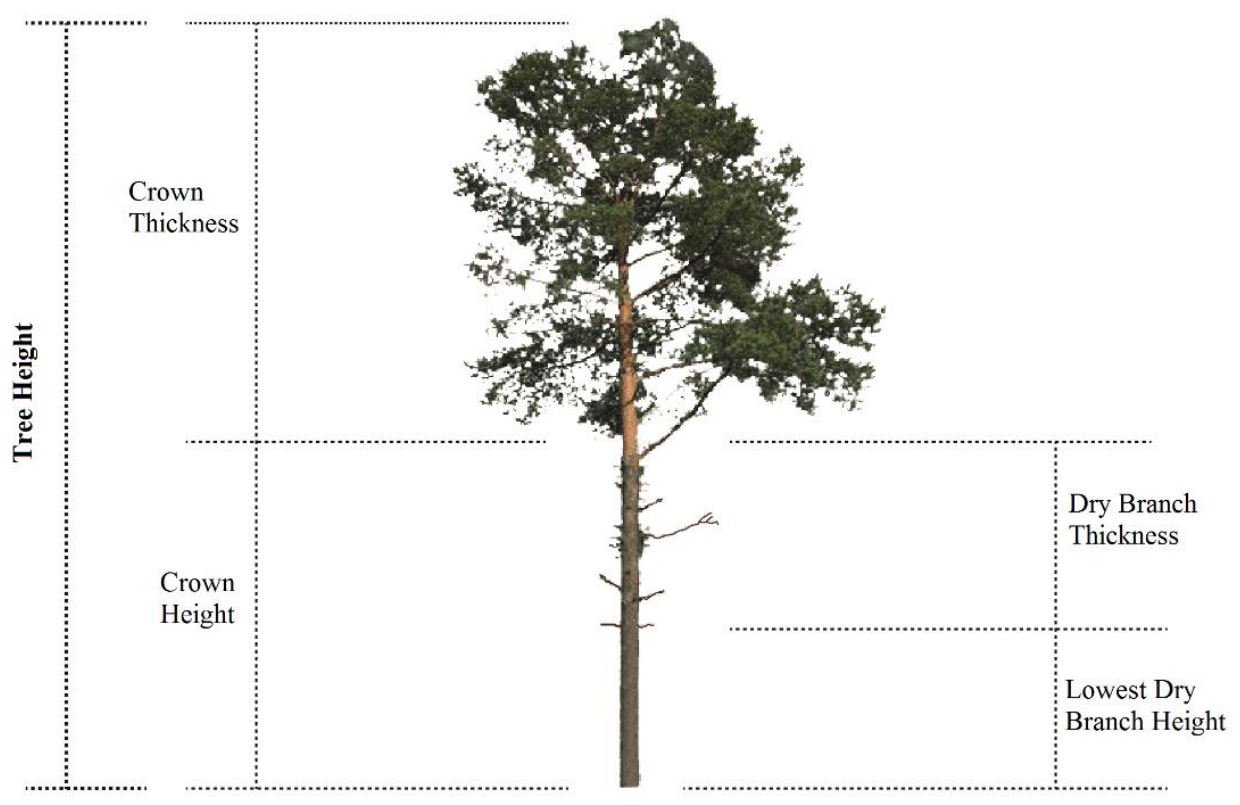

Figure 1. Diagram illustrating the tree sections subjected to forest litter estimation models.

Diagrama de las secciones del árbol que se midieron para derivar los modelos de estimación del mantillo. 
Table 1. Descriptive statistics of stand and individual tree parameters $(\mathrm{N}=105$ sampling plot $)$.

Estadísticas descriptivas de los parámetros de parcelas y árboles individuales ( $\mathrm{N}=105$ parcela de muestreo).

\begin{tabular}{|c|c|c|c|c|c|}
\hline & Variables & Minimum & Maximum & Mean & Standard deviation \\
\hline \multirow{11}{*}{ 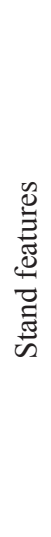 } & Age & 22.00 & 207.00 & 85.49 & 40.42 \\
\hline & Canopy closure (\%) & 0.30 & 1.00 & 0.73 & 0.15 \\
\hline & Stand volume $\left(\mathrm{m}^{3}\right)$ & 49.61 & 1449.53 & 440.16 & 222.88 \\
\hline & Productivity index & 8.06 & 34.27 & 21.94 & 5.21 \\
\hline & Productivity class & 1.00 & 5.00 & 3.02 & 1.12 \\
\hline & Stand density degree & 0.26 & 1.44 & 0.79 & 0.22 \\
\hline & Stand diameter breast height area $\left(\mathrm{m}^{2}\right)$ & 12.91 & 78.52 & 45.31 & 12.83 \\
\hline & Mean stand diameter breast height $(\mathrm{cm})$ & 7.74 & 58.83 & 27.85 & 10.73 \\
\hline & Major stand height (m) & 6.25 & 30.18 & 19.38 & 5.99 \\
\hline & Mean stand height (m) & 4.95 & 30.10 & 17.78 & 6.13 \\
\hline & Thinning rate $(\%)$ & 0.00 & 52.32 & 12.63 & 13.47 \\
\hline \multirow{6}{*}{ 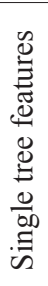 } & Lowest dry branch height (m) & 0.30 & 16.90 & 5.35 & 3.47 \\
\hline & Crown height (m) & 1.43 & 19.62 & 8.80 & 4.37 \\
\hline & Height (tree height) (m) & 3.97 & 27.39 & 15.19 & 5.74 \\
\hline & Dry branch thickness (m) & 0.76 & 7.77 & 3.45 & 1.61 \\
\hline & Crown thickness (m) & 2.19 & 11.05 & 6.40 & 1.83 \\
\hline & Lowest dry branch height/Height* & 0.05 & 0.65 & 0.31 & 0.12 \\
\hline
\end{tabular}

* Lowest dry branch height/Height $=($ Lowest dry branch height/Height $) * 100$

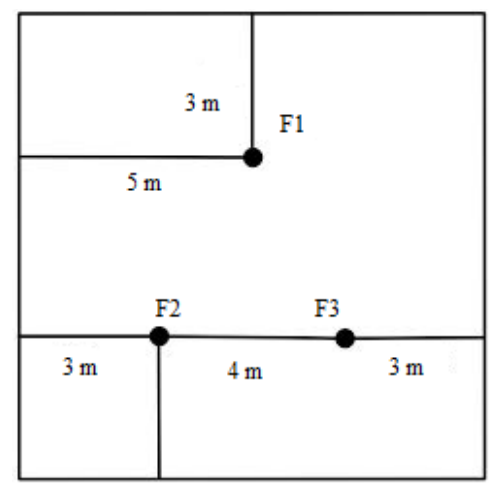

(A)

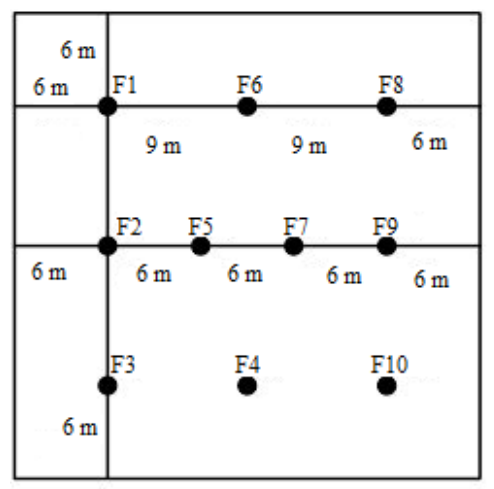

(C)

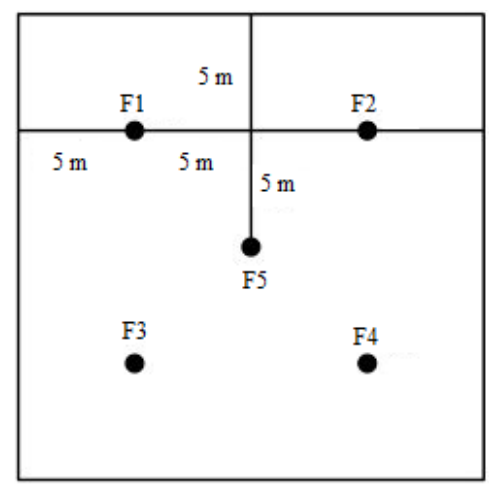

(B)

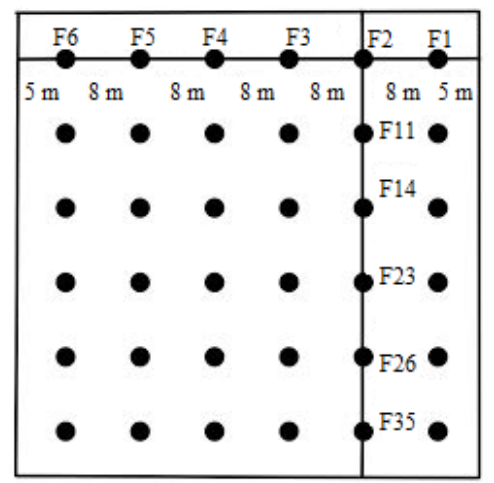

(D)

Figure 2. Forest litter sample collection points (F1-35) in A) 100, B) 400, C) 900 and D) 2,500 $\mathrm{m}^{2}$ plots of black pine. Sitios de colección (F1-35) de muestras del mantillo en parcelas de A) 100, B) 400, C) 900 y D) $2.500 \mathrm{~m}^{2}$. 


\section{RESULTS}

Forest litter fraction distribution in age classes. The forest litter fractions as fine forest litter and coarse woody debris did not present significant difference among stand ages. The mean sum of total fine forest litter fractions was $89 \mathrm{Mg} / \mathrm{ha}$ and coarse woody debris fractions were $6.5 \mathrm{Mg} /$ ha of total forest litter in all stand ages. The amount of $<2 \mathrm{~mm}$ and 2-4 mm fraction of forest litter were 2 to $5 \mathrm{Mg} /$ ha higher in young stands than in mature and old stands. On the other hand, we found 2 times higher bark and cone in coarse woody debris fractions at old and mature stands (figure 3).

Relationship between stand age and forest litter fractions. Twenty, 63 and 22 plots were sampled from the stands for ages $<50,50-100$ and $>100$, respectively. Total forest litter amounts varied from 18 to $213 \mathrm{Mg} / \mathrm{ha}$ with average quantities of 98,96 and $91 \mathrm{Mg} / \mathrm{ha}$ at young, mature and old stands, respectively.

The most prominently relevant variants used in the models were productivity index and dry branch thickness for young stands $\left(\mathrm{R}^{2}=0.43\right)$. For mature stands, the most suitable variables for equations were dry branch thickness, lowest dry branch height/height, dry branch thickness/ height, stand volume, crown height, productivity index and major stand height ( $\mathrm{R}^{2}$ ranged between 0.15 and 0.39 ). For old stands, the suitable variables used for equations were mean diameter, age, dry branch thickness and productivity index ( $\mathrm{R}^{2}$ ranged between 0.30 and 0.67) (table 2).

Considering the total forest litter dry biomass, the most prominent variants for young stands is thinning rate (positive correlation); for mature stands are dry branch thickness (positive correlation), lowest dry branch height/ height (positive correlation) and major stand height (negative correlation); and for old stands are mean diameter (positive correlation) and age (negative correlation).

\section{DISCUSSION}

The wide range of forest litter amounts in sampled plots is a function of heterogeneous crown structure (Penne et al. 2010). In the study conducted by Maguire (1994), annual branch mortality ranged from 33 to $430 \mathrm{~g} / \mathrm{m}^{2}$ crown projection area for individual trees, and from 236 to 1,035 $\mathrm{kg} / \mathrm{ha}$ for individual plots (Maguire 1994). In the current study, the amounts of total forest litter ranged between 18 and $213 \mathrm{Mg} / \mathrm{ha}$ and averages are 98,96 and $91 \mathrm{Mg} / \mathrm{ha}$ for young, mature and old stands, respectively, with insignificant differences (ANOVA $P>0.05$ ) (figure 3B). Woodall et al. (2012) stated that forest litter exhibited a high variance in terms of spatial distribution and landform. The differences between the lowest and highest amounts of floor litter might be caused by (i), uneven spatial distribution of trees in a stand, (ii) the competition among trees for light and acute dead stem incorporation to the forest litter (iii)
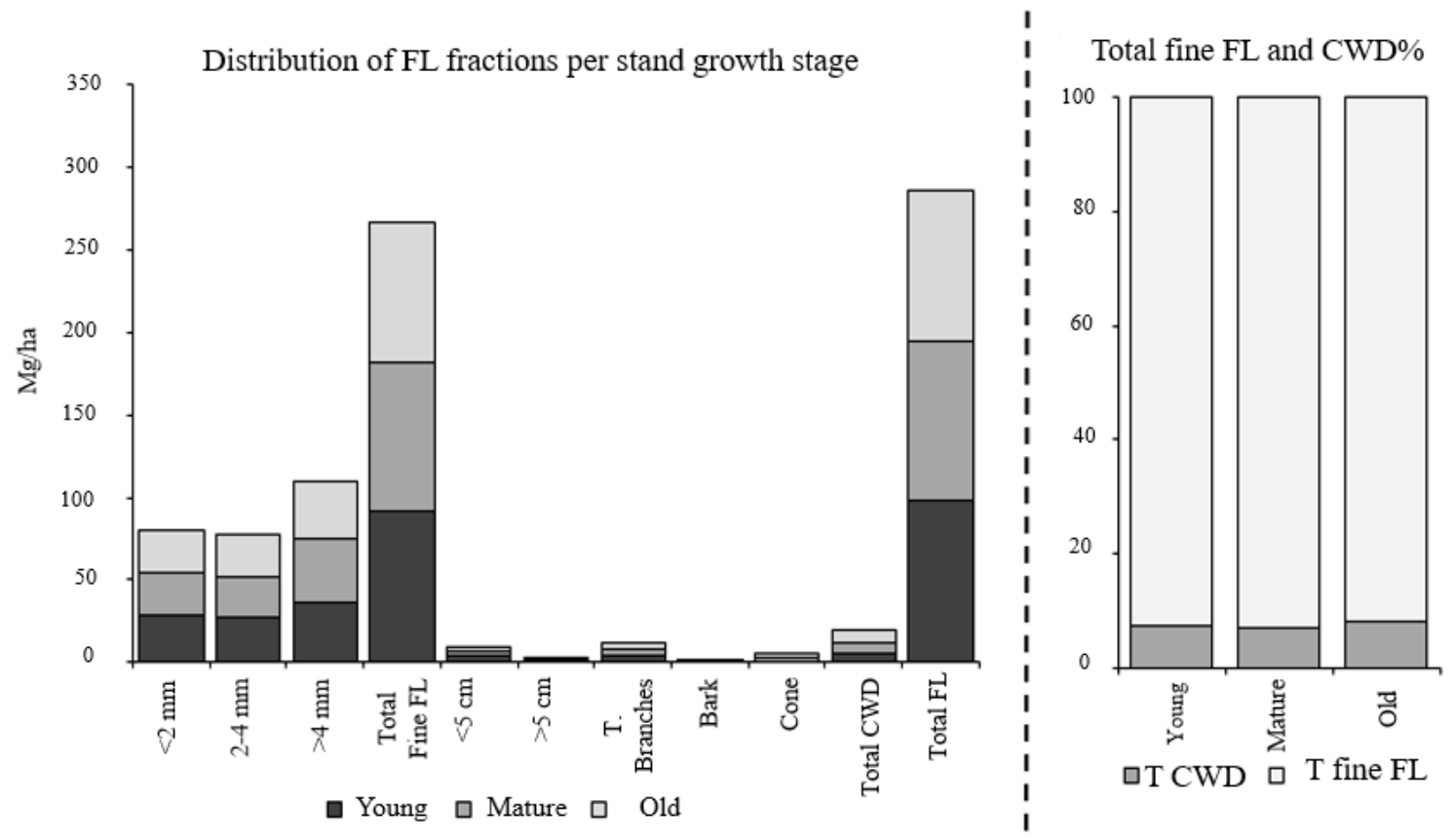

Figure 3. Comparison of amounts of forest litter fractions according to stand age: (A) Distribution of forest litter fractions ( $\mathrm{Mg} / \mathrm{ha}$ ) per stand growth stage, (B) Comparison of total fine forest litter and coarse woody debris (\%).

Comparación de las cantidades de los componentes del mantillo según la edad de los árboles: (A) distribución de las fracciones del mantillo del bosque (FL) (Mg/ha) según estado de crecimiento del rodal. (B) La comparación total de suelo fino del bosque y el porcentaje (\%) del grosor de los desechos de madera. 
Table 2. Model parameters for estimation of forest litter fractions according to age classes ${ }^{\#}$.

Parámetros del modelo para estimar los componentes del mantillo según la edad del rodal.

\begin{tabular}{|c|c|c|c|c|c|c|c|}
\hline $\begin{array}{l}\text { Estimated forest } \\
\text { litter components }\end{array}$ & Age class & Equation & $\mathrm{R}^{2}$ & Std. error & Df (Total)* & $\mathrm{F}$ & $P$ \\
\hline \multirow{3}{*}{$<2 \mathrm{~mm}$} & Young & $23962.5+(788.9 \times \mathrm{TR})$ & 0.20 & 21,507 & 19 & 4.463 & 0.049 \\
\hline & Mature & $14849.1+(5653.1 \times \mathrm{DBT})-(23.5 \times \mathrm{SV})$ & 0.22 & 13,328 & 62 & 8.355 & 0.001 \\
\hline & Old & $(1520.1 \times \mathrm{MD})-(274.9 \times \mathrm{Age})-34291.0$ & 0.58 & 14,174 & 21 & 13.344 & 0.001 \\
\hline \multirow{3}{*}{$2-4 \mathrm{~mm}$} & Young & $23311.7+(641.5 \times \mathrm{TR})$ & 0.28 & 14,088 & 19 & 6.876 & 0.017 \\
\hline & Mature & $\begin{array}{l}(1297.15 \times \mathrm{DBT} / \mathrm{H})+(337.49 \times \mathrm{LDBH} / \mathrm{H}) \\
-15877.2\end{array}$ & 0.31 & 9,597 & 62 & 13.728 & 0.001 \\
\hline & Old & $(6389.0 \times \mathrm{DBT})+(1231.6 \times \mathrm{MD})-44347.0$ & 0.67 & 10,822 & 21 & 19.343 & 0.001 \\
\hline \multirow{2}{*}{$>4 \mathrm{~mm}$} & Mature & $34021.5+(7825.0 \times \mathrm{DBT})-(3812.4 \times \mathrm{CT})$ & 0.32 & 13,888 & 62 & 14.060 & 0.001 \\
\hline & Old & $(5934.9 \times \mathrm{DBT})+(967.8 \times \mathrm{MD})-23057.0$ & 0.43 & 15,302 & 21 & 7.195 & 0.005 \\
\hline \multirow{3}{*}{ Total fine forest litter } & Young & $80093.1+(1978.1 \times \mathrm{TR})$ & 0.26 & 45,494 & 19 & 6.271 & 0.022 \\
\hline & Mature & $81067.2+(18207.6 \times \mathrm{DBT})-(2730.1 \times \mathrm{PI})$ & 0.33 & 31,896 & 62 & 14.936 & 0.001 \\
\hline & Old & $19721.7+(4606.2 \times \mathrm{MD})-(777.0 \times \mathrm{Age})$ & 0.64 & 34,409 & 21 & 16.758 & 0.001 \\
\hline$<5 \mathrm{~cm}$ & Mature & $1504.6+(52.80 \times \mathrm{LDBH} / \mathrm{H})$ & 0.29 & 1,872 & 62 & 5.604 & 0.021 \\
\hline Total branches & Mature & $1415.6+(78.89 \times \mathrm{LDBH} / \mathrm{H})$ & 0.30 & 2,689 & 62 & 6.064 & 0.017 \\
\hline Bark & Young & $(59.5 \times \mathrm{PI})-(388.8 \times \mathrm{DBT})-105.8$ & 0.43 & 363 & 19 & 6.324 & 0.009 \\
\hline \multirow{3}{*}{ Cone } & Young & $(69.9 \times \mathrm{PI})-522.7$ & 0.27 & 667 & 19 & 6.476 & 0.020 \\
\hline & Mature & $609.1+(343.5 \times$ DBT $)$ & 0.15 & 1,263 & 62 & 10.898 & 0.002 \\
\hline & Old & $(238.1 \times \mathrm{PI})-2366.2$ & 0.30 & 1,431 & 21 & 8.476 & 0.009 \\
\hline \multirow{3}{*}{ Total forest litter } & Young & $85792.2+(2003.1 \times \mathrm{TR})$ & 0.26 & 45,663 & 19 & 6.382 & 0.021 \\
\hline & Mature & $\begin{array}{l}60685.8+(21003.2 \times \mathrm{DBT})+(1144.58 \times \\
\mathrm{LDBH} / \mathrm{H})-(4156.4 \times \mathrm{MSH})\end{array}$ & 0.39 & 31,681 & 62 & 12.516 & 0.001 \\
\hline & Old & $28299.4+(4727.8 \times \mathrm{MD})-(823.7 \times \mathrm{Age})$ & 0.62 & 36,943 & 21 & 15.731 & 0.001 \\
\hline
\end{tabular}

"The parameters for which no equation could be established were removed.

*: Abbreviations in the table: Df: Degree of freedom; F: F value; $P$ : significance of probability; TR: Thinning rate; DBT: Dry branch thickness; SV: Stand volume; MD: Mean diameter, DBT/H: Dry branch thickness/Height; LDBH/H: Lowest dry branch height/Height; CT: Crown thickness; PI: Productivity index, MSH: Major Stand Height.

indirect effects of management practices such forest operations, log skidding.

The selected stand and individual tree parameters in this study such as canopy closure (Penne et al. 2010), stand density (Hennessey et al. 1992), tree height (Saarsalmi et al. 2007), diameter at breast height (Starr et al. 2005), crown height and crown thickness (Mäkinen et al. 2003) and dry branch thickness (Maguire 1994) were examined to ascertain their impact on forest litter fractions and distribution. According to the age classification, fine forest litter fraction appears to be a positive function of the thinning rate in younger stands; dry branch thickness and height in mature stands, and mean diameter and dry branch thickness in old stands. Similar variables such as thinning rate, dry branch thickness and mean diameter also existed in the equations established for total fine forest litter. Mäkinen et al. (2003) stated that the lowest dry branch height was lower at planted stands compared to naturally recruited Scots pine stands. This result is attributed to vigor competition at younger stages of stand development and different stand densities. The thinning rate factor used in models reflected similar conditions with the study of Mäkinen et al. (2003).

Coarse woody debris amounted from 6.6 to $7.8 \%$ of total forest litter samples and branches $<5 \mathrm{~cm}$ contributed with the largest portion of coarse woody debris (from 12.4 to $26.4 \%$ ) to total forest litter. According to results of our study, lowest dry branch height/height was the most remarkable variable on snag content of coarse woody debris. Higher lowest dry branch height means addition of more snag and branch content as coarse woody debris to the forest litter. Natural pruning with insufficient light penetration into the stands should be the most obvious reason for this observation (Montgomery and Chazdon 
2001). Coarse woody debris accumulation and distribution patterns often vary with live tree characteristics (Hale et al. 1999). In a boreal Picea abies (L.) Karst. forest study, mean stand height is the most important factor affecting total litter fall production (Saarsalmi et al. 2007). In the conceptual model (equation 1), branch basal diameter outside bark and depth into crown are the independent variants (Maguire 1994):

$$
\mathrm{W}_{\mathrm{B}}=\mathrm{b}_{1} \mathrm{DOB}^{\mathrm{b} 2} \mathrm{DINC}^{\mathrm{b} 3}
$$

Where: $\mathrm{W}_{\mathrm{B}}$ refers to branch litter biomass; $\mathrm{DOB}$ refers to basal diameter outside bark $(\mathrm{cm})$ and DINC refers to depth into crown (m), b1, b2 and b3 are calculated constants for the created model.

Matala et al. (2008) determines that stand-level litterfall was closely correlated with basal area and stand volume regardless of tree species. According to a study by Starr et al. (2005), total litterfall and needle litterfall are strongly related to stand basal area, and needle litterfall has a weak negative but significant correlation with stand age.

Some studies supported our results of observing higher amounts of coarse woody debris in old forests than in young stage of forests (Carmona et al. 2002). According to Olejiyugbe et al. (2011), aboveground coarse woody debris varies between 7 and $19 \mathrm{Mg} / \mathrm{ha}$ in a 35 years old intermediate forest. For the growth periods investigated, larger trees and trees growing in denser plots tend to produce greater necromass through branch mortality (Maguire, 1994). Contrastingly, the ratio of fallen branches to whole biomass varies from 0.5 to $6 \%$ with higher values at the lowest diameter breast height in scots pine forests (Finland) (Lehtonen et al. (2004).

The regression coefficients of the equations $\left(R^{2}\right.$ values of equations) to estimate forest litter fractions and amounts ranged between 0.15 and 0.67 . Positive correlation of thinning rate with the forest litter dry biomass is the only variant revealing a relation with total forest litter in young forests $\left(\mathrm{R}^{2}=0.26\right)$. As harvesting residuals are left in the stands, increased thinning rate causes more forest litter accumulation. Similarly, it is known that there is a decrease of total forest litter during the early stage of stands after clear cutting due to lower leaf and woody litterfall (Covington 1981). The positive contribution of thinning rate effect on tiny parts of forest litter is extremely meaningful since elevated level of thinning permits sun light to penetrate into the stand and decomposition of leaf litter by concomitant increases at dry biomass in decomposition and humus layers. The attempts to establish equations to estimate coarse woody debris failed because of insignificant $P$ values (>0.05) for regression value of $\mathrm{R}^{2}$. Lindenmayer et al. (1999) also recorded no significant results related to estimating log volumes between stands of different ages. Besides, the lowest dry branch height/height parameter correlates with the branches $>5 \mathrm{~cm}$ and total branch amounts in mature stands. Higher lowest dry branch height/height parameter means more branch secession which in turn causes addition of more branches to forest litter. The use of the lowest dry branch height parameter itself may not be proper because it is a dependent value of total tree-height; thus, lowest dry branch height/height parameter has provided a practical way to make an estimation for branch portion to the forest litter.

According to our results, productivity index for a given site has provided an estimate for cone amount distribution in forest litter in young and old stands, while cone dry biomass in forest litter was a function of dry branch thickness in mature stands. A study by Calama et al. (2008) stated that higher productivity index (PI), lower stand density and higher tree diameter cause higher cone production. Our findings are in consistence with the results obtained by their research.

\section{CONCLUSIONS}

Our results revealed that thinning intensity influences the accumulation of organic matter and rates of nutrient cycling. Forest litter differentiation should be regarded as it relates to stand thinning practices. The most prominent parameters in our regression models were dry branch thickness, thinning rate, height and age with positive $\mathrm{R}^{2}$ values ranging between 0.11 and 0.67 . Although the measurement of the dry branch thickness parameter is not as easy as thinning rate, height or average age of the stand, it provides quick access to the forest litter amounts for temperate black pine forests. Since the distribution range of forest litter shows a wide range as seen in the study region, those parameters might be perceived as practical. The generated models could have explained up to only two third of the total forest litter dry biomass. Failure of establishing some equations could be caused from the uneven distribution of forest litter in the sampled stands because of heterogeneous thinning. The unexplained parts of the equations are assumed to be the interferences of factors such as climate and micro/macro topography. Hereby, we can conclude that the amount of forest litter fractions can be estimated between 11 and $67 \%$ by measuring the relevant stand parameters such as dry branch thickness, thinning rate, height and age of the forest stand.

\section{ACKNOWLEDGEMENTS}

This study has been supported by TUBITAK (The Scientific and Technological Research Council of Turkey) with the project number $104 \mathrm{O} 551$. H. Barış Tecimen acknowledges to TUBITAK for financial support by BIDEB-2219 Postdoctoral Research Program in University of Florida under Project No: 1059B191501147. We are grateful to our previous affiliated foundation Istanbul University for providing us laboratory and office facilities. We would like to thank Dr. Alan L. WRIGHT for his inva- 
luable contributions to our manuscript and for language editorship. We are thankful to Dr. Ronald D. CAVE and Dr. Liliano M. CANO for their contribution to translation of abstract from English into Spanish. We thank Dr. Mert EKŞI for his contributions to improve our figures.

\section{REFERENCES}

Anonymous. 2006. Orman varlığımız. Publication of General Directorate of Forestry. Ankara, Turkey. 160 p.

Calama R, Gordo FJ, S Mutke, G Montero. 2008. An empirical ecological-type model for predicting stone pine $(P i$ nus pinea L.) cone production in the Northern Plateau (Spain). Forest Ecology and Management 255(3-4): 660673. DOI: $10.1016 /$ j.foreco.2007.09.079

Carmona MR, JJ Armesto, JC Aravena, CA Pérez. 2002. Coarse woody debris biomass in successional and primary temperate forests in Chiloé Island, Chile. Forest Ecology and Management 164: 265-275.

Carnol M, M Bazgir. 2013. Nutrient return to the forest floor through litter and throughfall under 7 forest species after conversion from Norway spruce. Forest Ecology and Management 309: 66-75. DOI: 10.1016/j.foreco.2013.04.008

Clutter LL. 1983. Compatible growth and yield models for loblolly pine. Forest Science 9(3): 354-370.

Covington WW. 1981. Changes in forest floor organic matter and nutrient content following clear cutting in northern hardwoods. Ecology 62(1): 41-48. DOI: $10.2307 / 1936666$

Fahey TJ, PB Woodbury, JJ Battles, CL Goodale, SP Hamburg, SV Ollinger, CW Woodall. 2010. Forest carbon storage: ecology, management, and policy. Frontiers in Ecology and the Environment 8(5): 245-252. DOI: 10.1890/080169

Goodale CL, MJ Apps, RA Birdsey, CB Field, LS Heath, RA Houghton, JC Jenkins, GH Kohlmaier, W Kurz, S Liu, G-J Nabuurs, SNilsson, AZ Shvidenko. 2002. Forest carbon sinks in the northern hemisphere. Ecological Applications 12(3): 891-899. DOI: 10.1890/1051-0761(2002)012[0891:FCSIT $\mathrm{N}] 2.0 . \mathrm{CO} ; 2$

Hale CM, J Pastor, KA Rusterholz. 1999. Comparison of structural and compositional characteristics in old-growth and mature, managed hardwood forests of Minnesota, U.S.A. Canadian Journal of Forest Research 29: 1479-1489. DOI: 10.1139/x99-076

Hennessey TC, Dougherty PM, Cregg BM, RF Wittwer. 1992. Annual variation in needle fall of a loblolly pine stand in relation to climate and stand density. Forest Ecology and Management 51(4): 329-338. DOI: 10.1016/03781127(92)90332-4

Kalıpsız A. 1982. Orman Hasılat Bilgisi. İstanbul, Turkey. İstanbul Üniversitesi, Orman Fakültesi, Yayın No: 3052/328. 349 p.

Lehtonen A, Sievänen R, Mäkelä A, Mäkipää R, Korhonen KT, T Hokkanen. 2004. Potential litterfall of Scots pine branches in southern Finland. Ecological Modelling 180(2): 305315. DOI: $10.1016 / \mathrm{j}$. ecolmodel.2004.04.024
Lindenmayer DB, Incoll RD, Cunningham RB, CF Donnelly. 1999. Attributes of logs on the forest floor of Australian Mountain Ash (Eucalyptus regnans) forests of different ages. Forest Ecology and Management 123: 195-203. DOI: 10.1016/S0378-1127(99)00047-X

Lučić A, S Mladenović-drinić, N Stavretović, V Isajev, V Lavadinović, L Rakonjac, M Novaković. 2010. Genetic diversity of Austrian pine (Pinus nigra Arnold) populations in Serbia revealed by RAPD. Archives of Biological Science Belgrade 62(2): 329-336. DOI: 10.2298/ABS1002329L

Maguire DA. 1994. Branch mortality and potential litterfall from Douglas-fir trees in stands of varying density. Forest Ecology and Management 70(1-3): 41-53. DOI: $\underline{10.1016 / 0378-}$ 1127(94)90073-6

Mäkinen H, R Ojansuu, P Sairanen, H Yli-ojola. 2003. Predicting branch characteristics of Norway spruce (Picea abies (L.) Karst.) from simple stand and tree measurements. Forestry 76(5): 525-546. DOI: $10.1093 /$ forestry/76.5.525

Matala J, S Kellomäki, T Nuutinen. 2008. Litterfall in relation to volume growth of trees: analysis based on literature. Scandinavian Journal of Forest Research 23(3): 194-202. DOI: $10.1080 / 02827580802036176$

Montgomery RA, RL Chazdon. 2001. Forest structure, canopy architecture, and light transmittance in tropical wet forests. Ecology 82(10): 2707-2718. DOI: 10.2307/2679955

Olajuyigbe SO, B Tobin, P Gardiner, M Nieuwenhuis. 2011. Stocks and decay dynamics of above-and belowground coarse woody debris in managed Sitka spruce forests in Ireland. Forest Ecology and Management 262(6): 1109-1118. DOI: $\underline{10.1016 / \text { j.foreco.2011.06.010 }}$

Penne C, B Ahrends, M Deurer, J Böttcher. 2010. The impact of canopy structure on the spatial variability in forest litter stocks. Geoderma 158: 282-297. DOI: 10.1016/j.geoderma.2010.05.007

Ranius T, O Kindvall, N Kruys, BG Jonsson. 2003. Modelling dead wood in Norway spruce stands subject to different management regimes. Forest Ecology and Management 182: 13-29. DOI: 10.1016/S0378-1127(03)00027-6

Saarsalmi A, M Starr, T Hokkanen, L Ukonmaanaho, M Kukkola, P Nöjd, R Sievänen. 2007. Predicting annual canopy litterfall production for Norway spruce (Picea abies (L.) Karst.) stands. Forest Ecology and Management 242(2): 578-586. DOI: 10.1016/j.foreco.2007.01.071

Sevim M. 1954. Alaçam (Dursunbey) Ormanlarında Ekolojik ve Pedolojik Araştırmalar. Istambul, Turkey. Orman Umum Müd, Yayımlarından Sıra Nu:131, Seri Nu:2, Çelikcilt Matbaas1. 64 p.

Starr M, A Saarsalmi, T Hokkanen, P Merilä, HS Helmisaari. 2005. Models of litterfall production for Scots pine (Pinus sylvestris L.) in Finland using stand, site and climate factors. Forest Ecology and Management 205(1): 215-225. DOI: $10.1016 /$ j.foreco.2004.10.047

Woodall CW, CH Perry, JA Westfall. 2012. An empirical assessment of forest litter carbon stock components across the United States. Forest Ecology and Management 269: 1-9. DOI: $\underline{10.1016 / \text { j.foreco.2011.12.041 }}$ 